\title{
APPLICATION OF 3D ANALYSIS TECHNOLOGY OF VISION SYSTEM IMAGE IN SPORTS MEDICINE
}

\author{
APLICAÇÃO DA TECNOLOGIA DE ANÁLISE 3D DE IMAGENS DO SISTEMA DE VISÃO NA \\ MEDICINA ESPORTIVA
}

Original Article

ARTIGO ORIGINAL

Artículo Original

\section{APLICACIÓN DE LA TECNOLOGÍA DEANÁLISIS 3D DE LA IMAGEN DEL SISTEMA DE VISIÓN EN MEDICINADEPORTIVA}

\section{Pei Jiang ${ }^{1}$ (ID \\ (Physical Education Professional) \\ 1. School of Public Fundamentals, Jiangsu Vocational College of Medicine, Yancheng, China.}

\section{Correspondence:}

Pei Jiang

School of Public Fundamentals, Jiangsu Vocational College of Medicine, Yancheng, 224006, China.jiangpeijsvcm@163.com

\begin{abstract}
Background: Objective: The study of sports biomechanics in sports medicine usually requires a special image analysis system (software) to obtain 3D kinematics data. Taking the swimming project in sports medicine as an example, 3D water images in water have always been relatively complicated and difficult. As light travels in different media, it will refract and reflect. When testing underwater movements, if only a land camera or an underwater camera is used for testing, the error caused by light refraction will be larger, which will affect the accuracy of the test data even more. Methods: Taking breaststroke movement as an example, a three-dimensional measurement method based on the Kwon3D movement analysis system is introduced. This method is different from the simple underwater camera test. It is a three-dimensional test method combining a land camera and an underwater camera. Two underwater cameras and two land cameras were used to simultaneously calibrate the water and underwater space with the same calibration frame in the experiment after analyzing and verifying the accuracy of 3D reconstruction. Results: The comprehensive reconstruction error is small, and the average relative error is less than 1\%. Conclusions: The application of three-dimensional image analysis technology of vision systems in sports medicine is reasonable and worth promoting. Level of evidence Il; Therapeutic studies - investigation of treatment results.
\end{abstract}

Keywords: Sports Medicine; Biomechanical phenomena; Water movements; Movement.

\section{RESUMO}

Antecedente: Objetivo: O estudo da biomecânica do esporte na medicina esportiva geralmente requer o uso de um sistema especial de análise de imagens (software) para a obtenção de dados cinemáticos 3D. Tomando o projeto de natação na medicina esportiva como exemplo, a análise de imagens 3D da água na água sempre foi um teste relativamente complicado e difícil. À medida que a luz viaja em diferentes meios, ela refratará e refletirá. Ao testar movimentos subaquáticos, se apenas uma câmera terrestre ou subaquática for usada para o teste, o erro causado pela refração da luz será maior, o que afetará a precisão dos dados de teste ainda mais. Métodos: Tomando o movimento de nado peito como exemplo, um método de medição tridimensional baseado no sistema de análise de movimento Kwon3D é introduzido. Este método é diferente do teste simples de câmera subaquática. É um método de teste tridimensional que combina uma câmera terrestre e uma câmera subaquática. No experimento, duas câmeras subaquáticas e duas câmeras terrestres foram usadas para calibrar simultaneamente a água e o espaço subaquático com o mesmo quadro de calibração. Depois de analisar e verificar a precisão da reconstrução 3D. Resultados: O erro de reconstrução abrangente é pequeno e o erro relativo médio é inferior a 1\% Conclusões: A aplicação da tecnologia de análise de imagem tridimensional do sistema de visão na medicina esportiva é razoável e vale a pena promover. Nível de evidência Il; Estudos terapêuticos- investigação dos resultados do tratamento.

Descritores: Medicina esportiva; Fenômenos biomecânicos; Movimentos da água; Movimento.

\section{RESUMEN}

Antecedente: Objetivo: El estudio de la biomecánica del deporte en la medicina deportiva generalmente requiere el uso de un sistema de análisis de imágenes especial (software) para obtener datos de cinemática 3D. Tomando como ejemplo el proyecto de natación en medicina deportiva, el análisis de imágenes de agua en 3D en el agua siempre ha sido una prueba relativamente complicada y difícil. A medida que la luz viaja en diferentes medios, se refractará y reflejará. Al probar los movimientos bajo el agua, si solo se utiliza una cámara terrestre o una cámara submarina para realizar la prueba, el error causado por la refracción de la luz será mayor, lo que afectará aún más la precisión de los datos de la prueba. Métodos: tomando como ejemplo el movimiento de la brazada, se introduce un método de medición tridimensional basado en el sistema de análisis de movimiento Kwon3D. Este método es diferente 
de la simple prueba de cámara subacuática. Es un método de prueba tridimensional que combina una cámara terrestre y una cámara submarina. En el experimento, se utilizaron dos cámaras submarinas y dos cámaras terrestres para calibrar simultáneamente el agua y el espacio submarino con el mismo marco de calibración. Después de analizar y verificar la precisión de la reconstrucción 3D. Resultados: el error de reconstrucción integral es pequeño y el error relativo promedio es inferior al 1\%. Conclusiones: La aplicación de la tecnología de análisis de imágenes tridimensionales del sistema de visión en la medicina deportiva es razonable y vale la pena promoverla. Nivel de evidencia Il; Estudios terapéuticos-investigación de los resultados del tratamiento.

Descriptores: Medicina deportiva; Fenómenos biomecánicos; Movimientos del agua; Movimiento.

\section{INTRODUCTION}

The method of image analysis is one of the important methods for sports biomechanics to analyze human movements, obtain three-dimensional coordinates of analysis points, and calculate kinematic parameters. Usually, a special image analysis system (software) is used to obtain three-dimensional kinematic data. The underwater motion measurement is different from the land project. Due to the complexity of the underwater 3D camera and 3D analysis technology, the following difficulties exist: (1) high equipment requirements (at least an underwater camera is required); (2) the cause of underwater and water sports The difference in light transmission medium causes the water and underwater sports limbs cannot be imaged at one time; (3) During the analysis, the continuous motion information of a motion point may not be obtained from a single recorded video, at least it needs to be used selectively.As light travels in different media, it will refract and reflect. This article takes breaststroke as an example to introduce a three-dimensional motion analysis system based on Kown3D, which uses a combination of underwater and land camera calibration and analysis methods. This measurement method is theoretically more reasonable than using only underwater or only water testing, and greatly reduces the error due to light refraction. ${ }^{1}$

\section{METHODS}

\section{Test equipment and equipment}

In the early stage, first shoot the video on the spot, and in the later stage, the three-dimensional analysis, then import the edited video to analyze the measurement point. Beijing Taihe Zhongyi underwater acquisition system (2 underwater cameras), 2 sony high-definition cameras (shooting frequency $50 \mathrm{~Hz}$ ), Kwon3d three-dimensional calibration frame, flash, self-made LED light, medical tape and double-sided tape. ${ }^{2}$

\section{Three-dimensional shooting scheme}

In this experiment, a three-dimensional fixed-point calibration camera method was used. Two Sony cameras were used on the water, and the shooting frequency was $50 \mathrm{~Hz}$. Two Beijing Taihe Zhongyi underwater camera systems were used underwater, and the flash-off light synchronization method was used in the later data sorting. Synchronize the four cameras (Figure 1).

The three-dimensional calibration frame is placed in the test area, that is, in the middle of the shooting range. The frame uses the cubic calibration frame provided by Kwon3D. The frame is about $1 \mathrm{~m}$ above the water surface (ensure that all three white balls on the vertical pole of the frame are above the water surface), that is, the $2 \mathrm{~m}$ high frame is half exposed on the water and half underwater ( Figure 2).The accuracy range of the measurement frame is about $3 m \times 3 m \times 2 m$ (Figure 3 ).

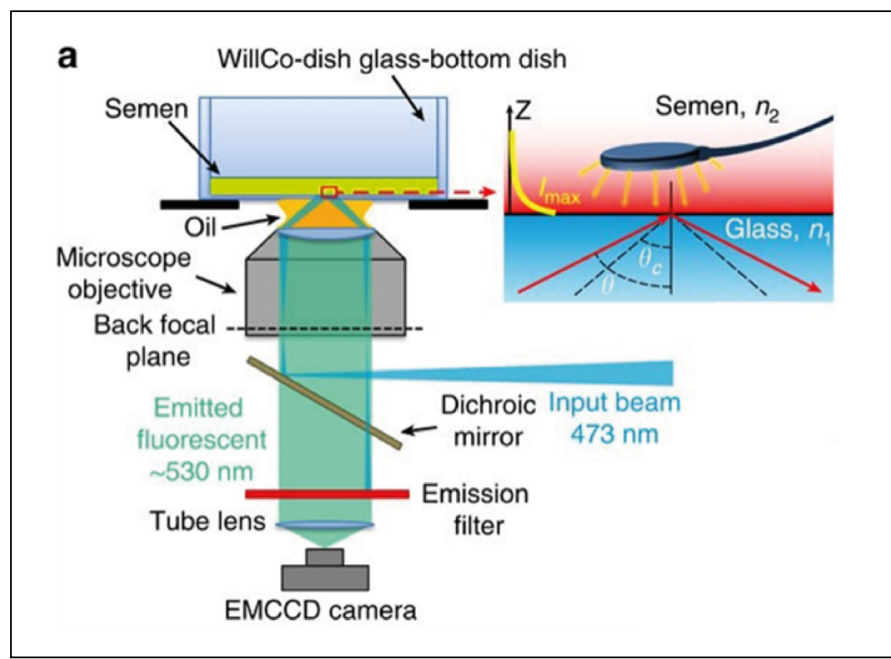

Figure 1. Stereo schematic view of test layout.
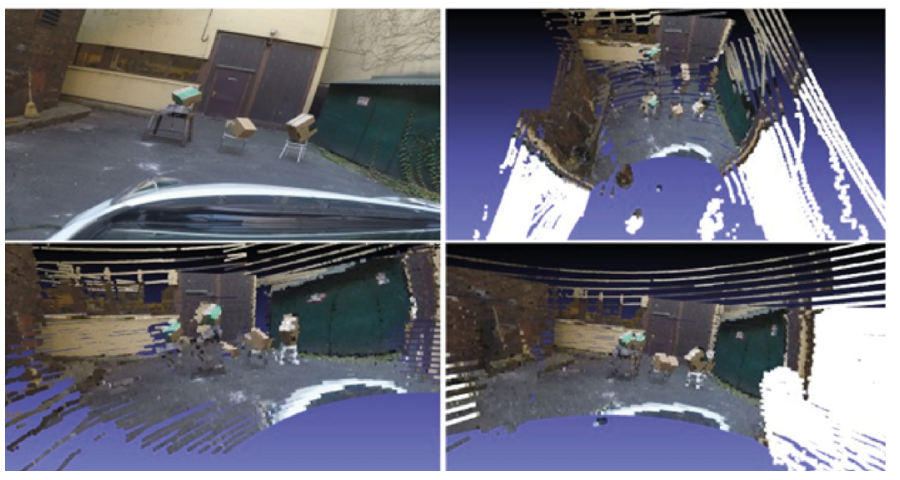

Figure 2. 4 cameras shooting calibration frame screen.

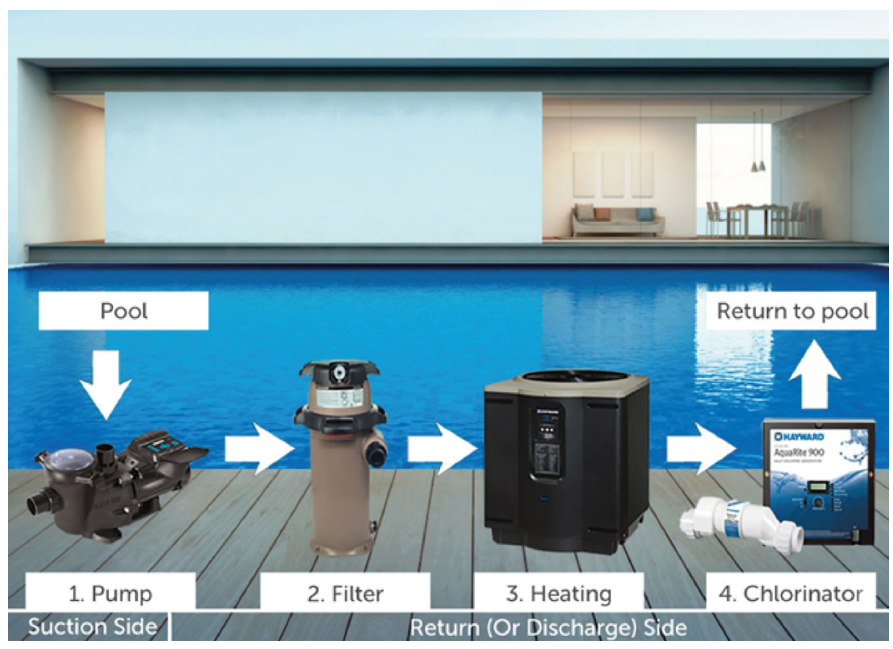

Figure 3. Schematic plan view of the test layout. 
Place the camera and the frame according to the position shown in the figure and debug them. In addition, the operator of the flash (located in the swim lane adjacent to the subject) presses the flash as much as possible while the subject swims through the shooting range, so that each camera can see this flash picture. ${ }^{3}$ For all shooting videos, this study used the non-linear editing software EDIUS for format conversion and editing, and then imported Kwon3d software for post-analysis.

\section{RESULTS}

\section{Frame calibration}

The calibration frame is a cubic structural frame matching the Kwon3d system. The length $\times$ width $\times$ height is $2 \mathrm{~m} \times 1 \mathrm{~m} \times 2 \mathrm{~m}$. The coordinates and errors of the 11 control points are shown in Table 1. In the calibration calculation interface, the Kwon3D system has two options for the three-dimensional reconstruction calculation method of calibration: DLT algorithm (direct linear conversion) and DSM (direct solution method). In this study, the DSM algorithm is selected to obtain the smallest reconstruction error. After multiple calibrations, the better one is selected, and the system shows that the "reconstruction error" is $0.306413 \mathrm{~cm}$ (Figure 4).

The FDK algorithm is an approximate three-dimensional image reconstruction algorithm proposed by Feldkamp et al. Most current three-dimensional accurate reconstruction algorithms are further developed on the basis of this algorithm. Figure 5 shows the geometric coordinate relationship of the cone beam circular scanning trajectory, where 0 - xyz represents the world coordinate system, $O$ - u v represents the detector projection data coordinate system, and $O$ - ts represents the ray source coordinate system. In addition, the z-axis is specified as

Table 1. Frame 36 control point coordinates and reconstruction error/cm

\begin{tabular}{c|c|c|c|c|c|c}
\hline Control point & $\mathbf{X}$ & $\mathbf{Y}$ & $\mathbf{Z}$ & $\mathbf{X r}$ & $\mathbf{Y r}$ & $\mathbf{Z r}$ \\
\hline Ctrl 1 & 0 & 0 & 20 & 0.07 & 0.01 & 19.92 \\
\hline Ctrl 2 & 0 & 0 & 50 & 0.03 & -0.21 & 50.07 \\
\hline Ctrl 3 & 0 & 0 & 80 & 0.15 & 0.01 & 80.04 \\
\hline Ctrl 4 & 0 & 100 & 20 & 0.16 & 99.86 & 20.24 \\
\hline Ctrl 5 & 0 & 100 & 50 & 0.06 & 99.81 & 50.25 \\
\hline Ctrl 6 & 0 & 100 & 80 & -0.21 & 99.84 & 80.16 \\
\hline Ctrl 7 & 100 & 0 & 20 & 100.09 & 0.01 & 19.6 \\
\hline Ctrl 8 & 100 & 0 & 50 & 100.2 & 0.05 & 49.68 \\
\hline Ctrl 9 & 100 & 0 & 80 & 100.07 & 0.01 & 79.76 \\
\hline Ctrl 10 & 100 & 100 & 20 & 100.5 & 99.89 & 19.81 \\
\hline Ctrl 11 & 100 & 100 & 50 & 100.08 & 100.07 & 49.72 \\
\hline
\end{tabular}

\section{b}

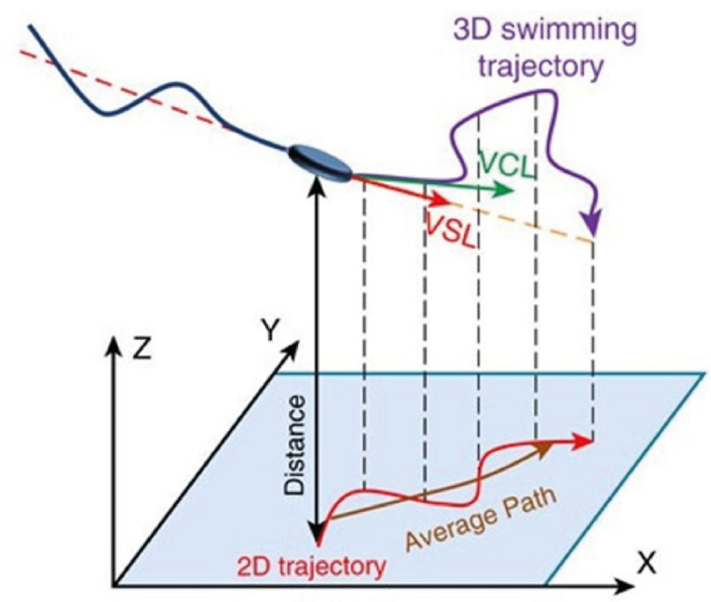

Figure 4. Screenshot of calibration calculation interface. the rotation center axis, and the s-axis always passes through the center of the ray source and is perpendicular to the detector plane. The FDK calculation formula is divided into two steps, as shown below:

(1) Filter

$$
P_{\theta}^{*}(i, j)=\left(\frac{d_{S D}}{\sqrt{d_{S O}^{2}+i^{2}+j^{2}}} P_{\theta}(i, j)\right) \cdot h(i)
$$

(2) Back projection

$$
f(x, y, z)=\int_{0}^{2 \pi} u^{2} P_{\theta}^{*}(p, q) d \theta
$$

among them,

$$
\left\{\begin{array}{l}
t=x \cos \theta+y \sin \theta, s=y \cos \theta-x \sin \theta \\
u=\frac{d_{S D}}{d_{S D}-s}, p=u t, q=u z
\end{array}\right.
$$

In the above formula, $d_{S D}$ represents the distance from the center of the ray source to the origin $O_{;} P_{\theta}(i, j), P_{\theta}(i, j)$ respectively represents the projection and filtered projection data at the rotation angle $\theta ; h$ (i)represents the convolution function; $(p, q)$ represents the inverse of the reconstructed voxel point on the filtered projection plane Projection point address; $f(x, y, z)$ represents the reconstructed image data at voxel point $(x, y, z)$.

Figure 6 shows the more intuitive geometric coordinate relationship of the three-dimensional cone beam circular scanning trajectory. Among them, $S$ is the center position of the ray source, $V(x, y, z)$ is the point to be reconstructed in the three-dimensional image, and $V^{\prime}(p$, $q$ ) is the point where $V$ intersects the flat panel detector along the ray direction. $\mathrm{D}$ is the center of the detector, uv rectangular coordinate system is the detector coordinate system, and $V^{\prime} D$ and $V$ axis form $\alpha$ angle. Cross the point $V$ to the straight-line SD and make a vertical line, and intersect with SD at point $M(m, n)$. The ts rectangular coordinate system is the ray source coordinate system, where the t-axis and the $x$-axis form an angle of $\theta$.

According to the geometric coordinate relationship

$$
\beta+\frac{\pi}{2}=\theta
$$

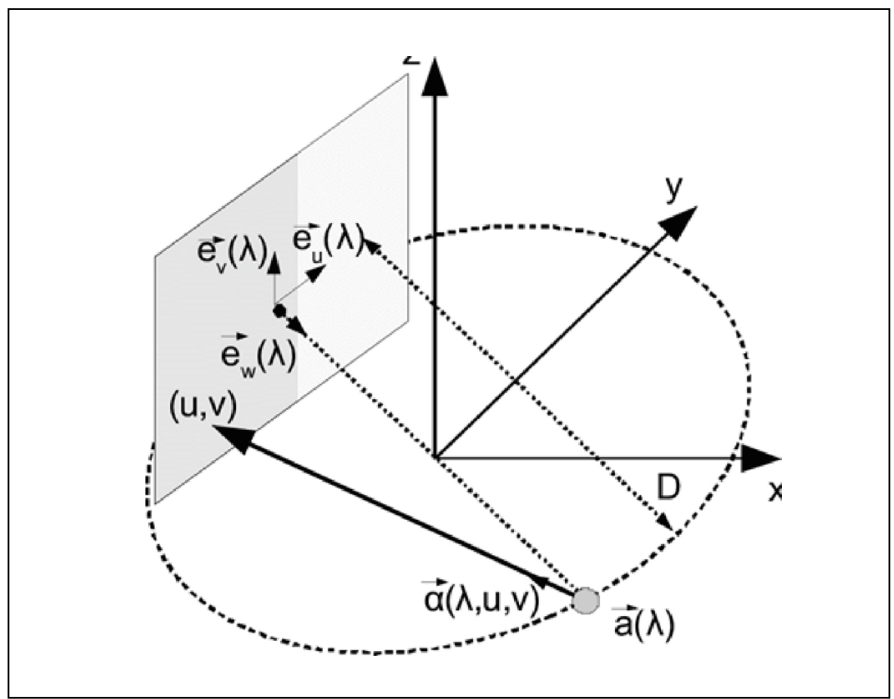

Figure 5. Geometric coordinate relationship of circular scanning trajectory of cone beam. 


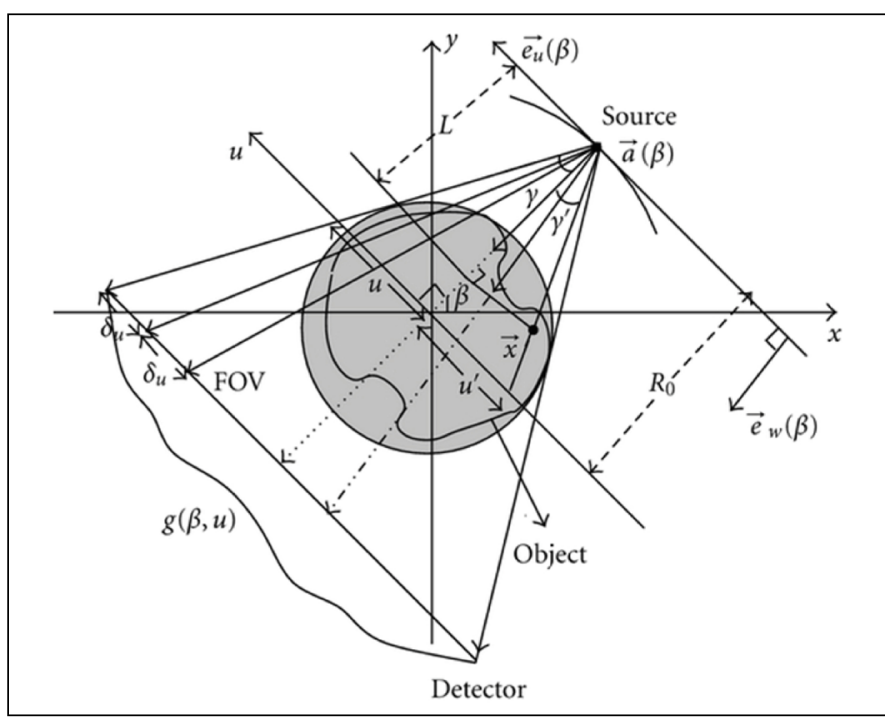

Figure 6. Geometric coordinate relationship of the three-dimensional cone beam circular scanning trajectory.

So, the coordinates of point $\mathrm{M}$ are

$m_{x}=d_{o m} \cos \beta=-d_{o m} \sin \theta$

$m_{y}=d_{o m} \sin \beta=-d_{o m} \cos \theta$

The distance between point $V$ and point is

$f(V, M)=\sqrt{(x-m)^{2}+(y-n)^{2}}=\sqrt{\left(x+d_{o m} \sin \theta\right)^{2}+\sqrt{\left(y-d_{o m} \cos \theta\right)^{2}}}$

\section{Verification of reconstruction accuracy}

This study uses a combination of water and underwater test methods to conduct breaststroke movement research, which is rarely seen in previous research literature. The verification method is: after shooting the calibration frame, let a staff member hold a calibration rod and swing it up and down in the calibration area. The swinging action includes swinging from the surface and inserting the rod into the water. The white balls with fixed spacing on the benchmark are measured. The measured data in Table 2 and Table 3 are continuous data within a short period of time. The time interval of the data is $0.02 \mathrm{~s}$, and the average errors are $-0.00394 \mathrm{~m}$ and $-0.002499 \mathrm{~m}$ respectively, that is, within the test range of $3 \mathrm{~m}$, the middle part of the test area The average relative error is $0.83 \%$ $\sim 0.66 \%$ (average relative error $=$ average error value / theoretical value), that is, the average relative error is less than $1 \%$. For current sports tests, especially underwater tests, this paper believes that the error produced by this calibration method is already very small, and it is an acceptable error range when measuring most of the commonly used "swim kinematic indicators".

\section{Measurement point analysis}

This test uses breaststroke as an example for testing. When establishing the model, only the point on one side is established, that is, only on the athlete's side. The joints of head, hand, wrist, elbow, shoulder, hip, knee, ankle, toe, and heel are analyzed. The inertial parameters of each link of the model are based on the system's own parameters, but the mass percentage of the head and torso is corrected by $1 / 2$ of the
Table 2. Actual measured data of white ball distances at both ends of the rod under sports.

\begin{tabular}{c|c|c}
\hline & 2 end white ball measured distance & Error/m \\
\hline 1 & 0.593592072 & -0.00641 \\
\hline 2 & 0.596475101 & -0.00352 \\
\hline 3 & 0.598215403 & -0.00178 \\
\hline 4 & 0.598884721 & -0.00112 \\
\hline 5 & 0.598694852 & -0.00131 \\
\hline 6 & 0.597933761 & -0.00207 \\
\hline 7 & 0.596907341 & -0.00309 \\
\hline 8 & 0.5958800008 & -0.00412 \\
\hline 9 & 0.595037206 & -0.00496 \\
\hline 10 & 0.594480911 & -0.00552 \\
\hline 11 & 0.594241102 & -0.00576 \\
\hline 12 & 0.594315284 & -0.00568 \\
\hline 13 & 0.594705138 & -0.00529 \\
\hline 14 & 0.595461301 & -0.00454 \\
\hline
\end{tabular}

Table 3. The measured data of the distance between the white ball in the middle of the rod and the white ball at one end under the motion.

\begin{tabular}{c|c|c}
\hline & $\begin{array}{c}\text { The measured distance between the white ball } \\
\text { at one end and the white ball at one end }\end{array}$ & Error/m \\
\hline 1 & 0.298179 & -0.00182 \\
\hline 2 & 0.294381 & -0.00562 \\
\hline 3 & 0.292173 & -0.00783 \\
\hline 4 & 0.291515 & -0.00849 \\
\hline 5 & 0.292249 & -0.00775 \\
\hline 6 & 0.294097 & -0.0059 \\
\hline 7 & 0.29668 & -0.00332 \\
\hline 8 & 0.299571 & -0.00043 \\
\hline 9 & 0.302371 & 0.002371 \\
\hline 10 & 0.304762 & 0.004762 \\
\hline 11 & 0.306543 & 0.006543 \\
\hline average value & 0.297502 & -0.002499 \\
\hline
\end{tabular}

original data, which is used for the relevant calculation of the human center of gravity data, which forms a human body "unilateral model".

Regarding the center of gravity of the human body, since the model is a "unilateral model", the three-dimensional coordinate data of the center of gravity of the whole body cannot be calculated during the calculation of the center of gravity. The movement is analyzed and tested, and then the overall three-dimensional movement of the center of gravity is analyzed, and the degree of left and right shaking during body movement can be analyzed. ${ }^{4}$

\section{DISCUSSION}

The process of digitizing the spatial coordinates of the selected measurement points, such as the manual "pointing" process of joint points such as shoulders, elbows, wrists, hips, knees, and ankles. For some key phase kinematic parameters, the interpretation error brought by the analyst sometimes exceeds the difference of the movement itself. The Kwon3D system can automatically connect the two parts of the data, and the data can be smoothly processed in the software as needed. For example, when analyzing the shoulder joint points, a certain period of time is managed by the image acquired by the underwater camera, and a certain period of time is managed by the image acquired by the camera on the water surface. During dot analysis, some necessary settings must also be made: when clicking the " $2 \mathrm{D}$ " button for measurement point analysis, the camera must be "paired" in The Camera Pairs option, and the two underwater cameras should be checked. In a group, select and match 2 cameras on the water to form a group. In this way, when 
generating three-dimensional data, the joint points located underwater are generated by the image of two cameras under the water. At some moments, the joint points are exposed to the water surface (such as head and shoulders), then the three-dimensional data is generated by the water 2 The camera images are "dotted". After all joints are parsed, click the "3D" button and the software automatically generates a three-dimensional stick figure. ${ }^{5}$

In addition, due to light and turbidity of the water in the swimming pool, the clarity of the image will be reduced. In order to improve the resolution of the image analysis, the self-made LED light can be attached to the position of the joint to be tested after the subject warms up. In the later image analysis, the position of the light-emitting lamp can be clearly seen, which provides an important reference for improving the analysis accuracy.

In theory, the three-dimensional test can test all the joint points of the subject, but due to the limited number of equipment, this study temporarily only performs three-dimensional movement test on the subject's limb. When the number of cameras is allowed, 4 underwater cameras, 4 water cameras or multi-machine synchronous tests can be carried out, three-dimensional data analysis of the limb movements on both sides can be performed, and the symmetry of the movement of the left and right limbs of the athlete can be studied in more detail. Make a more reasonable analysis of the center of gravity shift, etc.

\section{CONCLUSION}

Taking breaststroke as an example, this article provides a calibration and analysis method for three-dimensional measurement of swimming movements based on the Kwon3d three-dimensional analysis system. It is a three-dimensional test method that combines underwater and underwater cameras to further improve the water. The accuracy of motion 3D testing provides a meaningful reference. (2) The calibration method introduced in this paper theoretically further reduces the error caused by light refraction. In the test, the average relative error was less than $1 \%$. For current sports tests, especially water tests, this paper believes that the error caused by this calibration is an acceptable error range when measuring most commonly used swimming kinematics indicators.

The author declare no potential conflict of interest related to this article

AUTHORS' CONTRIBUTIONS: Pei Jiang designed provides a calibration and analysis method for three-dimensional measurement of swimming movements based on the Kwon3d three-dimensional analysis system, which The accuracy of motion 3D testing provides a meaningful reference.

\section{REFERENCES}

1. Huang L, Da F, Gai S. Research on multi-camera calibration and point cloud correction method based on three-dimensional calibration object. Optics \& Lasers in Engineering. 2019;115;32-41.

2. Ke Q, Wu S, Wang M, Zou Y. Evaluation of developer efficiency based on improved DEA model. Wireless Personal Communications. 2018;102(4);3843-9.

3. Li Y, De-Xing; Shu-liang Y; Institute of Industry and Trade Measurement Technique,China Jiliang
University; Research on measurement method of thermal diffusivity of materials based on thermography. Acta Metrologica Sinica. 2017;38(1);28-33.

4. Hong JP, Lee JJ, Yeo H, Kim CK, Pang SJ, Oh JK. Parametric study on the capability of three-dimensional finite element analysis (3d-fea) of compressive behaviour of douglas fir. Holzforschung. 2016;70(6);539-546.

5. Wu S, Wang M, Zou Y. Bidirectional cognitive computing method supported by cloud technology. Cognitive Systems Research. 2018;52;615-21. 